\title{
ANALISIS NILAI TAMBAH BUAH SALAK SEBAGAI BAHAN BAKU DODOL SALAK PADA UD MANDIRI DI DESA PANGU I KECAMATAN RATAHAN KABUPATEN MINAHASA TENGGARA
}

\author{
Juliana Raranta \\ Eyverson Ruauw \\ Nordy Fritsgerald Lucky Waney
}

\begin{abstract}
The objective of this research is to analyze and to compare the added value and profit of processing "salak" to "dodol salak" based on type of harvesting. This research was conducted for 3 months from April to June 2018 at UD Mandiri in Pangu I Village, Ratahan District, Southeast Minahasa. Data used are primary data obtained by interviewing to business owner using questionnaires. Data analysis of the data used is added value with the formula of NTp $=(N T p=N a-(B b+B p+B b p)$ and profit analysis using the formula $\pi=(\pi=$ $T R-T C)$. Results showed that businnes of "dodol salak" generate added value at big harvest (panen raya) is Rp. 19,399,652.78, at medium harvest (panen sedang) is Rp. 18,649,652.78, and at small harvest (panen kecil) is Rp. 17,749,652.78. The business profits of "dodol salak" at the big harvest (panen raya) is Rp. 8,499,652.78, at medium harvest (panen sedang) is Rp. 7,749,652.78, and at small harvest (panen kecil) is Rp. $6,849,652.78$. The highest added value of "dodol salak" at big harvest (panen raya) was 9.30 percent greater than at small harvest (panen kecil), and 4.02 percent that at the medium harvest (panen sedang). The highest business profit from "dodol salak" at the big harvest (panen raya) which was greater 24.09 percent than at the small harvest (panen kecil), and 9.68 percent than at the medium harvest (panen sedang). "
\end{abstract}

Keywords : added value, profit, salak fruit, "dodol salak".

\section{ABSTRAK}

Tujuan dari penelitian ini adalah untuk menganalisis dan membandingkan nilai tambah dan keuntungan dari pengolahan buah salak menjadi "dodol salak" berdasarkan jenis panen. Penelitian ini dilakukan selama 3 bulan dari April hingga Juni 2018 di UD Mandiri di Desa Pangu I, Kecamatan Ratahan, Minahasa Tenggara. Data yang digunakan termasuk data primer yang diperoleh dengan wawancara kepada pemilik usaha dan menggunakan kuesioner, dan data sekunder yang diperoleh dari berbagai literatur terkait dengan penelitian ini. Analisis data dari data yang digunakan adalah nilai tambah dengan rumus $\mathrm{NTp}=\mathrm{Na}-(\mathrm{Bb}+\mathrm{Bp}+\mathrm{Bbp})$ dan analisis profit menggunakan rumus $\pi=\mathrm{TR}$ - TC. Hasil penelitian menunjukkan bahwa usaha "dodol salak" menghasilkan nilai tambah dalam "panen raya" adalah Rp. 19,399,652.78, "panen sedang" adalah Rp. $18,649,652.78$, dan dalam "panen kecil" adalah Rp. 17.749.652,78. Keuntungan usaha dari "dodol salak" di "panen raya" adalah sebesar Rp. 8,499,652.78, "panen sedang" adalah Rp. 7,749,652.78, dan pada "panen kecil" adalah Rp. 6,849,652.78. Nilai tambah tertinggi dari usaha "dodol salak" pada saat "panen raya" dimana 9,30 persen lebih besar dari "panen kecil", dan 4,02 persen dibandingkan dengan "panen sedang". Keuntungan tertinggi dari usaha dari "dodol salak" pada saat "panen raya" dimana lebih besar 24,09 persen daripada "panen kecil", dan 9,68 persen dari "panen sedang"." "Ilreprm

Kata kunci: nilai tambah, keuntungan, buah salak, dodol salak.

\section{PENDAHULUAN}

\section{Latar Belakang}

Industri pengolahan hasil pertanian merupakan subsistem yang sangat penting dikembangkan untuk mendukung pembagunan pertanian. Dikembangkannya industri ini dapat memberikan nilai tambah dari produk pertanian dan membuka kesempatan kerja serta menyediakan produk makanan yang beragam (Herliska, 2017).
Dengan demikian, subsistem agroindustri mempunyai prospek yang baik di masa mendatang dan dapat diandalkan untuk memajukan perekonomian Indonesia.

Di Kabupaten Minahasa Tenggara terdapat beberapa jenis komoditas pertanian yang dapat diolah lebih lanjut menjadi produk yang bermutu serta bernilai tinggi, satu diantaranya adalah buah salak. Buah salak mempunyai peluang untuk dikembangkan karena potensinya yang baik untuk 
kegiatan agribisnis dan agroindustri. Buah salak ini tergolong komoditas hortikultra yang bersifat buah musiman serta mempunyai karakter yang mudah rusak sehingga umur simpannya relatif pendek (Putra, 2016). Buah salak hanya bisa bertahan setelah dipetik kurang lebih 6-7 hari.

Upaya untuk menghadapi masalah umur simpan salak yang relatif pendek tersebut adalah dengan melakukan pengolahan hasil pertanian. Buah salak sebagai bahan baku dodol salak banyak terdapat di Desa Pangu I Kecamatan Ratahan. Buah salak dapat menjadi bahan baku dalam usaha pengolahan dodol salak, keripik salak, manisan salak, sirup salak, kurma salak dan lain sebagainya. Tentunya nilai tambah dari buah salak ini dapat berbeda untuk berbagai usaha tersebut. Nilai tambah yang lebih besar akan dapat memberikan manfaat yang lebih besar lagi.

UD Mandiri merupakan usaha yang berada di Desa Pangu I yang bergerak dibidang industri pengolahan salak. Industri ini hanya mengolah buah salak menjadi dodol salak. Pembuatan dodol salak di lokasi penelitian masih menggunakan cara tradisional dengan menggunakan kayu bakar, tungku pengapian, wajan ukuran jumbo, sendok pengaduk adonan yang berbahan kayu dan alat pendukung lainnya. Selain itu UD Mandiri sering diundang oleh Pemerintah Pusat untuk ikut Festival ajang Nasional. Tujuan dari pengolahan dodol salak itu sendiri untuk meningkatkan nilai salak itu sendiri sehingga memperoleh nilai jual yang lebih tinggi di pasaran.

Berdasarkan survey diketahui bahwa musim panen buah salak itu terdiri dari musim panen raya, musim panen sedang, dan musim panen kecil. Panen raya (panen banyak) terjadi pada periode bulan November 2017 - Februari 2018, panen sedang (panen normal) terjadi pada periode bulan Juli 2017 - Oktober 2017, dan panen kecil (panen sedikit) terjadi pada periode bulan Maret 2017 - Juni 2017.

Buah salak yang ditawarkan oleh petani pada panen raya lebih banyak dibandingkan dengan kedua musim lainnya, dan musim panen sedang lebih banyak dibandingkan dengan musim panen kecil. Akibat dari jumlah buah salak yang ditawarkan oleh petani yang lebih banyak pada musim panen raya harga buah salak lebih rendah daripada musim panen sedang dan musim panen kecil, dan pada musim panen sedang lebih rendah daripada musim panen kecil.

Istilah nilai tambah (added value) itu sendiri sebenarnya menggantikan istilah nilai yang ditambahkan pada suatu produk karena masuknya unsur pengolahan menjadi lebih baik (Valentina, 2009). Dengan adanya industri yang mengubah bentuk primer menjadi produk baru yang lebih tinggi nilai ekonomisnya setelah melalui proses pengolahan, maka akan dapat memberikan nilai tambah dan keuntungan karena dikeluarkannya biaya-biaya sehingga terbentuk harga baru yang lebih tinggi bila dibandingkan tanpa melalui proses pengolahan (Manueke, 2016). Harga buah salak sebagai pembentuk nilai tambah dan keuntungan itu berbeda pada musim panen. Untuk memenuhi nilai ekonomis tersebut, sejauh ini baik dari UD Mandiri dan sumber dari yang lain belum pernah melakukan penelitian dan perhitungan adanya nilai tambah. Hal tersebut yang mendorong penulis untuk melakukan penelitian sehingga dapat mengetahui lebih lanjut mengenai nilai tambah dari buah salak menjadi dodol salak di Desa Pangu I Kecamatan Ratahan, dengan studi kasus pada UD Mandiri.

\section{Rumusan Masalah}

Masalah yang diteliti dirumuskan dalam bentuk pertanyaan penelitian yaitu berapa besarnya Nilai Tambah dan keuntungan yang diterima dari usaha pengolahan buah salak menjadi dodol salak pada UD Mandiri berdasarkan musim panen yaitu panen raya, panen sedang dan panen kecil?

\section{Tujuan Penelitian}

Menganalisis dan membandingkan besarnya Nilai Tambah dan keuntungan dari usaha pengolahan buah salak menjadi dodol salak pada UD Mandiri berdasarkan musim panen yaitu panen raya, panen sedang, dan panen kecil.

\section{Manfaat Penelitian}

Manfaat yang diharapkan dari peneliitian ini dapat menjadi informasi tentang nilai tambah bahan baku buah salak menjadi dodol salak. Penelitian ini diharapkan dapat menambah wawasan atau pengetahuan mengenai nilai tambah, serta dapat memberikan kontribusi bagi mahasiswa tentang nilai tambah produk-produk agroindustri.

\section{METODE PENELITIAN}

\section{Tempat dan Waktu Penelitian}

Penelitian ini dilakukan selama 3 bulan mulai dari April sampai Juni 2018 pada UD. Mandiri yang berlokasi di Desa Pangu I, Kecamatan Ratahan, Kabupaten Minahasa Tenggara. Usaha ini menjadi salah satu industri pengolahan buah salak menjadi dodol salak.

\section{Metode Pengumpulan Data}

Pengumpulan data meliputi data primer dan data sekunder. Data primer diperoleh melalui wawancara langsung pada pemilik usaha dodol salak dan karyawan (tenaga kerja) serta observasi 
langsung di tempat penelitian menggunakan data harga menurut musim (panen raya, panen sedang dan panen kecil), pada saat penelitian yang terjadi panen kecil. Data sekunder diperoleh dari berbagai literatur yang berhubungan dengan penelitian ini.

\section{Konsep Pengukuran Variabel} adalah :

Dalam penelitian ini variabel yang di ukur

1. Hasil Produksi dodol salak, yaitu hasil yang diperoleh dari setiap kali produksi $(\mathrm{kg})$.

2. Harga dodol salak, yaitu harga yang berlaku (Rp/Kemasan).

3. Biaya Tetap, yaitu biaya untuk faktor produksi tetap.

a. Biaya Penyusutan Alat, yaitu komponen biaya yang secara tidak langsung dikeluarkan untuk setiap produksi. Biaya penyusutan dihitung dengan formulasi :

$$
\mathrm{P}=\frac{H A-H B}{T}
$$

Ket. $\mathrm{P}=$ Biaya Penyusutan Alat $(\mathrm{Rp})$

$\mathrm{HA}=$ Harga Awal (Rp)

$\mathrm{HB}=$ Harga Akhir (Rp)

$\mathrm{T}=$ Umur Ekonomis (bulan/tahun)

4. Biaya Variabel, yaitu biaya faktor produksi variabel.

a. Biaya Bahan Baku, yaitu biaya yang dikeluarkan untuk bahan baku yang digunakan $(\mathrm{Rp} / \mathrm{kg})$.

b. Biaya Bahan Penolong, yaitu biaya yang dikeluarkan untuk bahan penolong yang digunakan $(\mathrm{Rp} / \mathrm{kg})$.

c. Biaya Tenaga Kerja, yaitu biaya yang dibayarkan kepada tenaga kerja (Rp/bulan).

5. Total Biaya, yaitu biaya tetap yang ditambah dengan biaya variabel (Rp).

6. Penerimaan, yaitu perkalian antara output yang dihasilkan dengan harga jual (Rp).

7. Biaya Antara, yaitu biaya-biaya yang dikeluarkan untuk biaya bahan baku, biaya penyusutan alat ditambah dengan biaya bahan penolong (Rp).

\section{Metode Analisis Data}

Analisis yang digunakan dalam penelitian ini adalah analisis keuntungan yaitu untuk melihat berapa keuntungan dari industri ini menggunakan rumus :

$$
\pi=\mathrm{TR}-\mathrm{TC}
$$

Ket. $\quad \pi=$ Keuntugan usaha (Rp)

$\mathrm{TR}=$ Total Penerimaan $(\mathrm{Rp})$

$\mathrm{TC}=$ Total Biaya $(\mathrm{Rp})$
Untuk Biaya Total dapat dihitung dengan mengunakan rumus sebagai berikut:

$$
\mathrm{TC}=\mathrm{TFC}+\mathrm{TVC}
$$

Ket.

$$
\begin{aligned}
\mathrm{TC} & =\text { Total Biaya }(\mathrm{Rp}) \\
\mathrm{TFC} & =\text { Total Biaya Tetap }(\mathrm{Rp})
\end{aligned}
$$

TVC $=$ Total Biaya Variabel $(\mathrm{Rp})$

Untuk menghitung Penerimaan dapat dihitung dengan menggunakan rumus sebagai berikut :

$$
\mathrm{TR}=\mathrm{Q} \times \mathrm{P}
$$

$\mathrm{K}$ et. $\mathrm{TR}=$ Total Penerimaan $(\mathrm{Rp})$

$\mathrm{Q}=$ Jumlah Produk

$\mathrm{P}$ = Harga Produk (Rp)

Analisis Nilai Tambah untuk menghitung besarnya pertambahan nilai dari dodol salak, yaitu :

$$
\begin{aligned}
\mathrm{NTp} & =\mathrm{Na}-(\mathrm{Bb}+\mathrm{Bp}+\mathrm{Bbp}) \\
& =\mathrm{Na}-\mathrm{Ba}
\end{aligned}
$$

Ket. $\quad$ NTp $=$ Nilai Tambah produk $(\mathrm{Rp}) / \mathrm{kg}$

$\mathrm{Na}=$ Nilai Produk $(\mathrm{Rp})$

$\mathrm{Ba}=$ Biaya antara $(\mathrm{Rp})$

$\mathrm{Bb}=$ Biaya Bahan Baku (Rp)

$\mathrm{Bp}=$ Biaya Penyusutan Alat (Rp)

$\mathrm{Bbp}=$ Biaya Bahan Penolong $(\mathrm{Rp})$

Analisis Nilai Tambah dan Keuntungan dilakukan menurut musim panen yaitu :

- Panen Raya : (panen banyak) terjadi periode bulan November 2017 - Februari 2018.

- Panen Sedang : (panen normal) terjadi periode bulan Juli 2017 - Oktober 2017.

- Panen Kecil : (panen sedikit) periode bulan Maret 2017 - Juni 2017.

Digunakan jenis panen bahwa terkait dengan waktu musim buah salak dan harga buah salak.

\section{HASIL DAN PEMBAHASAN}

\section{Deskripsi Umum Tempat Penelitian}

UD Mandiri merupakan usaha pengolahan dodol salak yang beroperasi sejak tahun 2006 dan berlokasi di Desa Pangu I, Kecamatan Ratahan, Kabupaten Minahasa Tenggara. UD Mandiri didirikan oleh Bpk Artje Sengkey. Bahan baku untuk pembuatan dodol salak dibeli dari petani salak lokal dengan harga Rp. 2.500 per kg salak pada panen raya, harga Rp. 5.000 per $\mathrm{kg}$ pada panen sedang dan harga Rp. 8.000 per kg salak pada panen kecil. Bahan baku utama yang digunakan dalam memproduksi dodol salak yaitu buah salak segar.

UD Mandiri memilih untuk memperhatikan beberapa hal terkait penggunaan bahan baku buah salak dalam memproduksi dodol salak yaitu dengan memiliki karakteristik daging buah berwarna cokelat muda, tekstur buah agak lunak, dan intinya buah salak tidak busuk. 
Produksi dodol salak dalam sebulan memakai $300 \mathrm{~kg}$ buah salak dengan hasil produksi sebanyak 4000 kemasan dodol salak. Harga yang diberikan untuk produk dodol salak ini adalah Rp. 7.000 per kemasan. Kegiatan produksi pengolahan dodol salak, tentunya membutuhkan proses yang tidak instant, dimana pada setiap tahap pembuatannya diperlukan control yang maksimal mulai dari tahap pengadaan bahan baku sampai dengan tahap akhir atau pengemasan produk.

Penggunaan peralatan dalam proses produksi pada usaha ini masih tradisional. Hal ini dikarenakan, minimnya modal usaha serta kurangnya pengetahuan dan pengoperasian akan teknologi pasca panen dan produksi. Selain itu juga pemilik masih memilih untuk menggunakan cara dan alat sederhana, untuk mendapatkan rasa dan bentuk produk yang alami. Tenaga kerja pada usaha ini berjumlah sepuluh orang. Diantaranya, empat tenaga kerja perempuan dan enam tenaga kerja laki-laki yang merupakan tenaga kerja lokal dari desa tersebut. Dalam memiih tenaga kerja, pemilik usaha tidak begitu peduli akan status pendidikan, akan tetapi lebih menekankan pada pengalaman, keterampilan dan kreatifitas para pekerjanya. Untuk pembagian pekerjaan, usaha ini masih menggunakan sistem bekerjasama yaitu saling melengkapi antara pekerja yang satu dengan pekerja yang lainnya, dalam artian bahwa setiap pekerja dapat merangkap semua jenis pekerjaan yang telah ditetapkan.

Pemasaran dodol salak ini umumnya ke kios-kios, toko oleh-oleh, supermarket, dengan jangkauan pasar hingga ke daerah Langowan, Kawangkoan, Tomohon, dan Manado. Target pemasaran yaitu semua kalangan, meliputi anakanak, remaja, dewasa, bahkan lansia.

\section{Penggunaan Peralatan}

Pengadaan peralatan yang tepat dapat membantu melancarkan proses kegiatan produksi serta dapat memberikan keuntungan bagi usaha pengolahan dodol salak. Alat-alat yang digunakan yaitu loyang aluminium, ember jumbo, wajan jumbo, sendok pengaduk adonan berbahan kayu, mesin giling kelapa, blender, nampan plastik, freezer, hekter, dan spatula. Biaya penggunaan peralatan pada usaha pengolahan dodol salak selama proses produksi, dapat dilihat pada Tabel 1.

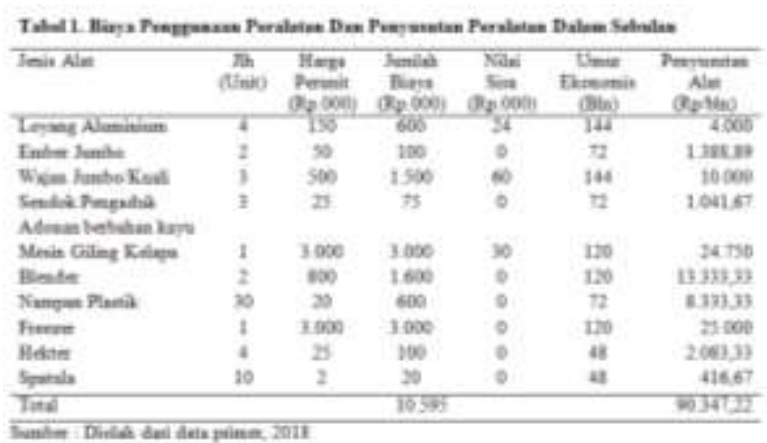

Tabel 1 memperlihatkan total biaya pengunaan peralatan yang dikeluarkan oleh usaha pengolahan buah salak menjadi dodol salak pada UD Mandiri di Desa Pangu I Kecamatan Ratahan sebesar Rp. 10.595.000, sedangkan total biaya penyusutan peralatan sebesar Rp. 90.347,22. Hal ini dikarenakan semua alat digunakan untuk setiap memproduksi dodol salak.

Kapasitas produksi dodol salak dalam sebulan ada sepuluh kali proses produksi hanya sebesar $300 \mathrm{~kg}$. Skala usaha dodol salak UD. Mandiri tidak dapat ditingkatkan karena permintaan dodol salak hingga saat ini hanya di Kota Manado dan Kabupaten Minahasa.

\section{Penyediaan Bahan Baku Dan Bahan Penolong}

Bahan baku utama yang digunakan dalam proses pengolahan dodol salak UD. Mandiri adalah buah salak. Bahan baku adalah bahan mentah yang diolah untuk menghasilkan produk pertanian dengan nilai yang lebih tinggi. Ketersediaan bahan baku secara stabil dan berkelanjutan dapat membantu proses produksi suatu usaha berjalan lancar dan usaha dapat beroperasi dalam waktu relatif lama, selain bahan baku ada juga bahan penujang atau bahan penolong lain yang dipakai produksi dodol salak UD. Mandiri, bahan penolong yang dipakai adalah gula aren, gula pasir, santan kelapa, tepung beras kentan, kayu bakar, daun janur (woka), pita, plastik bening, dan mika.

Bahan baku yang dipakai dalam proses produksi dodol salak UD Mandiri adalah buah salak yang di beli dari petani lokal desa Pangu dengan harga bahan baku utama Rp. 2.500 per $\mathrm{kg}$ pada panen raya (panen banyak) periode bulan November 2017-Februari 2018, harga bahan baku utama bahan baku utama Rp. 5.000 
per $\mathrm{kg}$ pada panen sedang (panen normal) periode bulan Juli-Oktober 2017, harga bahan baku utama Rp. 8.000 per kg pada panen kecil (panen sedikit) periode bulan Maret-Juni 2017. Sebulan proses produksi digunakan $300 \mathrm{~kg}$ buah salak yang menghasilkan $500 \mathrm{~kg}$ dodol salak., atau penggunaan buah salak dalam proses produksi sebesar $1 \mathrm{~kg}$ akan menghasilkan 1,67 kg dodol salak.

Berikut ini adalah rincian dari biaya bahan baku dan bahan penolong dalam sebulan proses produksi berdasarkan musim panen periode 2017-2018 yaitu (rincian biaya bahan baku dan bahan penolong dalam sebulan pada panen raya periode bulan November 2017, rincian biaya bahan baku dan bahan penolong dalam sebulan pada panen sedang periode bulan September 2018 dan rincian biaya bahan baku dan bahan penolong dalam sebulan pada panen kecil periode bulan Mei 2018 dapat dilihat pada Tabel 2 berikut.

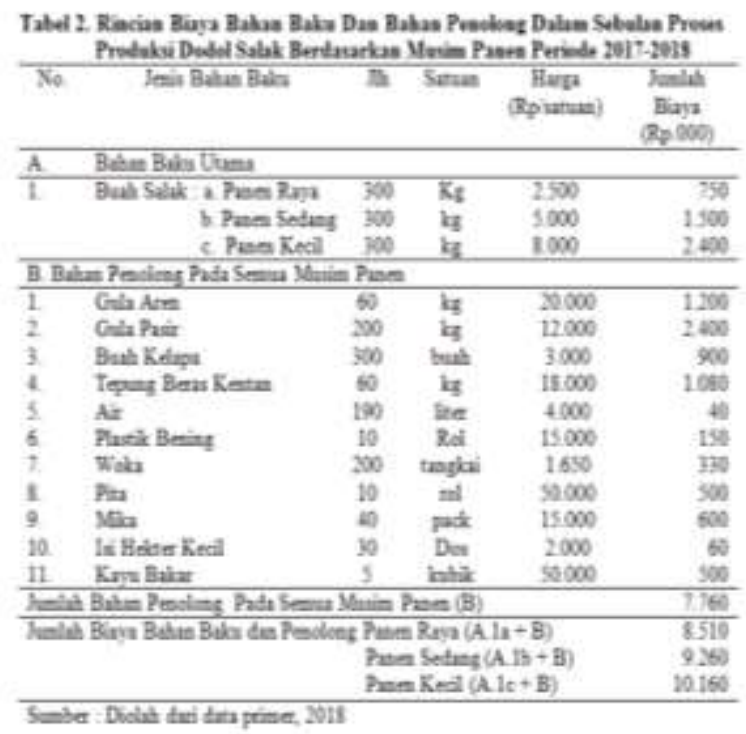

Tabel 2 merupakan rincian biaya pengunaan bahan baku dan bahan penolong yang diperlukan dalam sebulan ada sepuluh kali proses produksi dodol salak berdasarkan musim panen periode 2017-2018, biaya keseluruhan pengunaan bahan baku dan bahan penolong yang dikeluarkan pada panen raya sebesar Rp. 8.510 .000 , dimana biaya yang dikeluarkan dalam proses produksi dodol salak pada panen raya terbesar terletak pada bahan penolong yaitu gula pasir sebesar Rp. 2.400 .000 dan terendah juga pada bahan penolong yaitu air sebesar Rp. 40.000. Biaya keseluruhan penggunaan bahan baku dan bahan penolong yang dikeluarkan pada panen sedang sebesar Rp. 9.260.000, dimana biaya yang dikeluarkan dalam proses produksi dodol salak pada panen sedang terbesar terletak pada bahan penolong yaitu gula pasir sebesar Rp. 2.400 .000 dan terendah juga pada bahan penolong yaitu air sebesar Rp. 40.000. Biaya keseluruhan penggunaan bahan baku dan bahan penolong yang dikeluarkan pada panen kecil sebesar Rp. 10.160.000, dimana biaya yang dikeluarkan dalam proses produksi dodol salak pada panen kecil terbesar terletak pada bahan baku utama sebesar Rp. 2.400.000 dan bahan penolong yaitu gula pasir sebesar Rp. 2.400.000 dan terendah terletak pada bahan penolong yaitu air Rp. 40.000. Perbedaan biaya berdasarkan musim panen ini terletak pada biaya bahan baku utama.

\section{Biaya Produksi}

Semua biaya yang dikeluarkan untuk memproduksi suatu barang (produk). Ada dua jenis biaya produksi yaitu, biaya tetap dan biaya variabel. Biaya tetap pada penelitian ini meliputi biaya penyusutan alat dan biaya listrik. Sedangkan biaya variabel meliputi biaya bahan baku, biaya bahan penolong, dan biaya tenaga kerja.

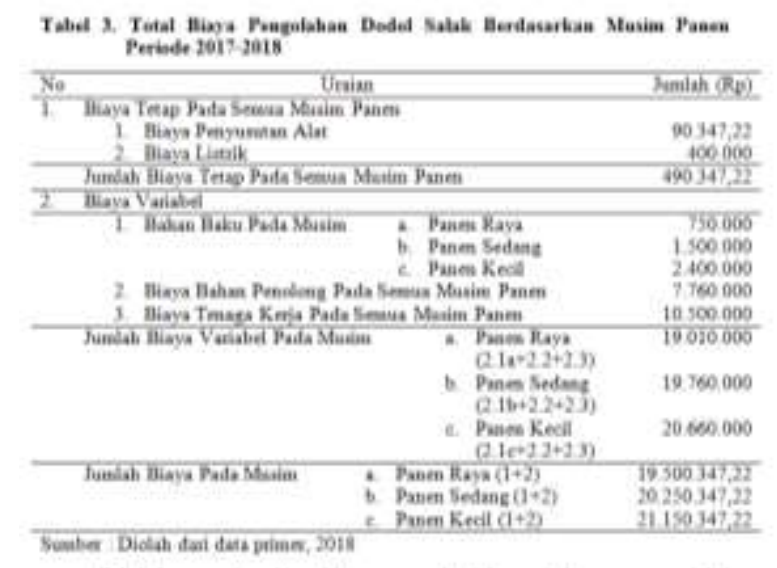

Tabel 3 merupakan biaya-biaya yang ada dalam sebulan proses produksi dodol salak UD Mandiri berdasarkan musim panen periode 2017-2018. Jumlah biaya tetap pada panen raya adalah sebesar Rp. 490.347,22 dan jumlah biaya variabel adalah sebesar Rp. 19.010.000, total biaya keseluruhan pada panen raya sebesar Rp.19.500.347,22. Jumlah biaya tetap pada panen sedang adalah sebesar Rp. 490.347,22 dan jumlah biaya variabel adalah sebesar Rp. 
19.760.000, total biaya keseluruhan pada panen sedang sebesar Rp. 20.250.347,22. Jumlah biaya tetap pada panen kecil adalah sebesar Rp. 490.347,22 dan jumlah biaya variabel adalah sebesar Rp. 20.660.000, total biaya keseluruhan pada panen kecil sebesar Rp. 21.150.347,22 dengan perincian yaitu biaya penyusutan alat, biaya listrik, biaya bahan baku, biaya bahan penolong, dan biaya tenaga kerja. Jumlah tenaga kerja sebanyak sepuluh orang dengan upah per orang sebesar Rp. 1.050 .000 per bulan proses produksi.

\section{Penerimaan Usaha}

Jumlah penerimaan usaha pengolahan buah salak menjadi dodol salak pada UD. Mandiri diperoleh dari perkalian antara harga jual dodol salak dengan jumlah dodol salak yang diproduksi. Jumlah dodol salak yang diproduksi oleh UD. Mandiri yaitu 4000 kemasan per bulan dalam sepuluh kali proses produksi dengan harga jual Rp. 7.000 per kemasan. Maka besar penerimaan yang diperoleh oleh UD. Mandiri setiap bulannya yaitu Rp. 28.000.000,00, walaupun harga bahan baku berbeda menurut musim panen tetapi harga jual dodol salak itu tetap atau tidak berubah. Rincian penerimaan usaha pengolahan dodol salak UD. Mandiri dapat dilihat pada Tabel 4 berikut.

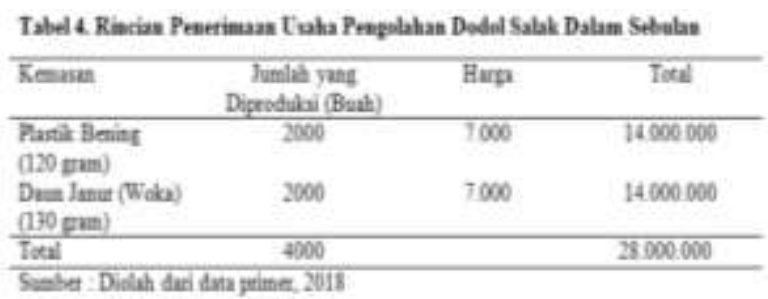

Tabel 4 memperlihatkan banyaknya produksi dodol salak dalam sebulan yang terbagi dalam dua kemasan. Setiap kemasan berisi sepuluh buah dodol salak yang dibungkus dengan plastik bening dan daun janur (woka). Berat dodol salak kemasan daun janur (woka) sebesar 130 gram sedangkan berat kemasan plastik bening sebesar 120 gram.

\section{Analisis Nilai Tambah}

Perhitungan analisis nilai tambah usaha pengolahan buah salak menjadi dodol salak pada UD Mandiri dilakukan untuk mengetahui besarnya nilai yang ditambahkan pada bahan baku yang digunakan yaitu buah salak. Berikut adalah Tabel 5 yang menunjukkan nilai tambah dodol salak berdasarkan musim panen.

Tabel 5. Nilai Tambah Dodol Salak Berdasarkan Musim Panen

\begin{tabular}{|c|c|c|}
\hline No & Jenis Panen & Nilai Tambah (Rp) \\
\hline 1. & Panen Raya & $19.399 .652,78$ \\
\hline 2. & Panen Sedang & $18.649 .652,78$ \\
\hline 3. & Panen kecil & $17.749 .652,78$ \\
\hline
\end{tabular}

Sumber : Diolah dari data primer, 2018

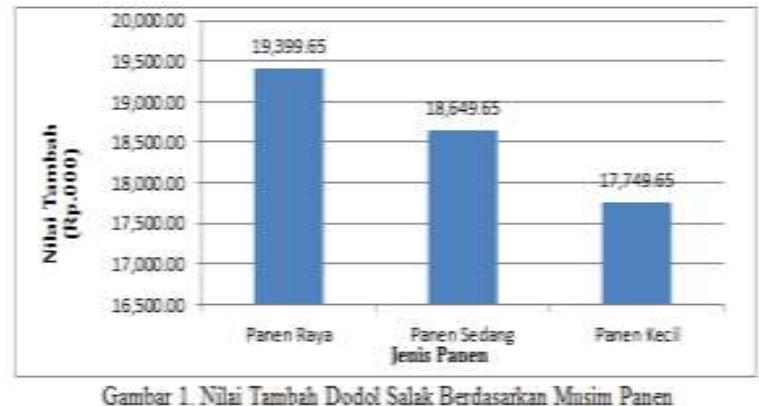

Berdasarkan Tabel 5 dan Gambar 1 nilai tambah dari buah salak menjadi dodol salak pada panen raya sebesar Rp. 19.399.652,78, pada panen sedang sebesar Rp. 18.649.652,78, dan pada panen kecil sebesar Rp. 17.749.652,78. Besarnya perbedaan nilai tambah ini disebabkan karena harga berdasarkan Tabel 2 dan 3. Perbedaan nilai tambah menurut musim dipengaruhi oleh harga bahan baku pada musim dimana jumlah produksi lebih banyak harga bahan baku itu lebih rendah, semakin rendah harga bahan baku nilai tambah itu semakin besar.

Nilai tambah dodol salak dibagi dengan jumlah bahan baku yaitu sebesar $300 \mathrm{~kg}$ buah salak pada semua musim maka diperoleh besarnya nilai tambah per $\mathrm{kg}$ buah salak. Hasil bagi tersebut diperoleh sebesar Rp. 64.666 pada musim panen raya, Rp. 62.166 pada musim panen sedang, dan Rp. 59.166 pada musim panen kecil, angka tersebut memberi arti bahwa untuk setiap $1 \mathrm{~kg}$ buah salak yang diolah menjadi dodol salak dapat memberikan penambahan nilai pada musim panen raya sebesar Rp. 64.666, pada musim panen sedang sebesar Rp. 62.166, dan pada musim panen kecil sebesar Rp. 59.166.

Nilai tambah musim panen raya terjadi kenaikan harga Rp.64.666 atau penambahan 
nilai 25,87 persen, pada musim panen sedang terjadi kenaikan harga Rp. 62.166 atau penambahan nilai 12,43 persen, dan pada musim panen kecil terjadi harga kenaikan $\mathrm{Rp}$. 59.166 atau penambahan nilai 7,40 persen.

\section{Keuntungan Usaha}

Tujuan dari setiap usaha adalah mendapatkan keuntungan yang besar dan selalu berkelanjutan. Sehingga keuntungan yang diperoleh dari usaha pengolahan buah salak menjadi dodol salak adalah selisih antara total penerimaan dengan total biaya yang ada dalam usaha ini. Besarnya keuntungan yang dapat diperoleh UD. Mandiri dalam sebulan pada panen raya periode bulan November 2017, pada panen sedang periode bulan September 2018 dan panen kecil periode bulan Mei 2018.

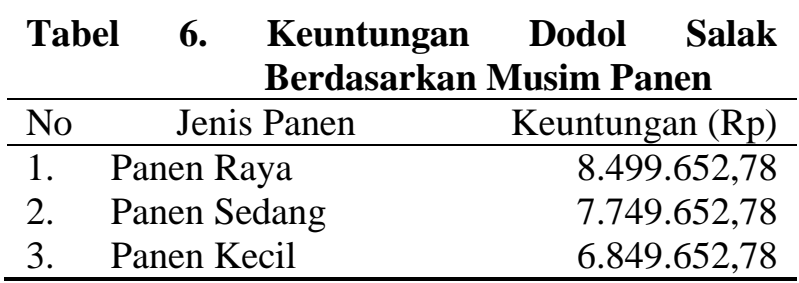

Sumber : Diolah dari data primer, 2018

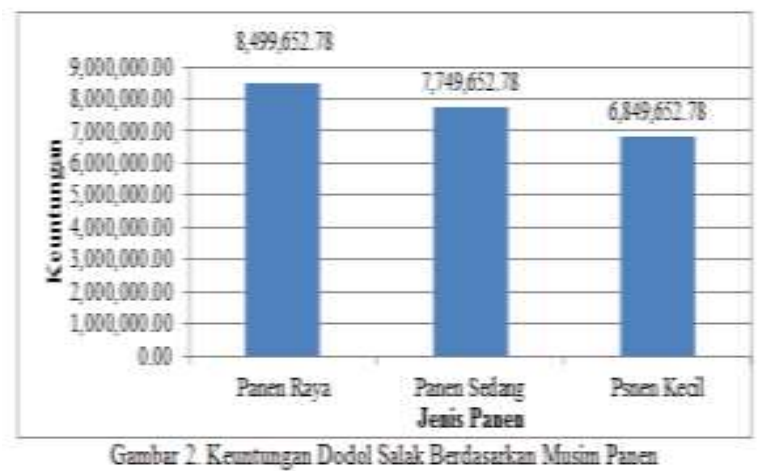

Berdasarkan Tabel 6 dan Gambar 2 keuntungan dari buah salak menjadi dodol salak pada panen raya sebesar Rp. 8.499.652,78, pada panen sedang sebesar Rp. 7.749.652,78, dan pada panen kecil sebesar Rp. 6.849.652,78. Besarnya perbedaan keuntungan ini disebabkan karena harga berdasarkan Tabel 2 dan 3 . Perbedaan keuntungan menurut musim dipengaruhi oleh harga bahan baku pada musim dimana jumlah produksi lebih banyak harga bahan baku itu lebih rendah, semakin rendah harga bahan baku keuntungan itu semakin besar.
Total biaya yang digunakan untuk dodol salak pada panen raya sebesar Rp. 19.500.347,22, pada panen sedang sebesar Rp. 20.250.347,22, pada panen kecil sebesar Rp. 21.150.347,22 dengan menggunakan bahan baku utama buah salak sebanyak $300 \mathrm{~kg}$ menghasilkan 2000 kemasan ukuran 120 gram dan 2000 kemasan ukuran 130 gram. Usaha dodol salak pada semua musim panen memperoleh penerimaan kotor sebesar Rp. 28.000.0000.

Keuntungan musim panen raya terjadi kenaikan harga atau penambahan nilai sebesar Rp.339.986,11, pada musim panen sedang terjadi kenaikan harga atau penambahan nilai Rp.154.993,06, dan pada musim panen kecil terjadi harga kenaikan atau penambahan nilai Rp.85.620,66.

\section{KESIMPULAN DAN SARAN}

\section{Kesimpulan}

Usaha pengolahan buah salak menjadi dodol salak menghasilkan nilai tambah pada musim panen raya sebesar Rp. 19.399.652,78, lebih besar 9,30 persen dibandingkan dengan musin panen kecil, dan 4,02 persen dibandingkan dengan musim panen sedang.

Keuntungan usaha dodol salak pada panen raya sebesar Rp. 8.499.652,78, lebih besar 24,09 persen dibandingkan dengan musim panen kecil, dan 9,68 persen dibandingkan dengan musim panen sedang pada tingkat harga Rp. 7.000 per kemasan dodol salak.

Perbedaan besarnya nilai tambah dan keuntungan menurut musim dipengaruhi oleh harga bahan baku, semakin besar nilai tambah dan keuntungan disebabkan karena harga bahan baku buah salak semakin rendah. Harga jual dodol salak tidak dipengaruhi oleh harga bahan baku buah salak.

\section{Saran}

Produk dodol salak yang diusahakan oleh UD Mandiri terus dikembangkan karena dapat menguntungkan dan memberikan nilai tambah baik pada panen raya, panen sedang dan panen kecil, dilihat dari panen raya yang sangat menguntungkan diharapkan Pemilik UD Mandiri memperbanyak produksi dodol salak dan mempromosikan dodol salak ke luar daerah yang berpotensi yang lebih besar. 


\section{DAFTAR PUSTAKA}

Herliska, A. Y. R. 2017. Analisis Pendapatan Dan Nilai Tambah Produk Olahan Berbahan Baku Salak Pada Skala Industri Rumah Tangga Di Kabupaten Sleman. Yogyakarta.

Manueke, R. 2016. Analisis Nilai Tambah Kacang Sangrai pada UD. Tarsius di Desa Kinnali Kecamatan Kawangkoan. Skripsi Fakultas Pertanian Universitas Sam Ratulangi. Manado.

Putra, T. T. 2016. Nilai Tambah Produk Olahan Berbahan Baku Salak Pondoh Skala Industri Rumah Tangga Di Desa Donokerto Kecamatan Turi Kabupaten Sleman. Skripsi Fakultas Pertanian Universitas Muhammadiyah. Yogyakarta.

Valentina, O. 2009. Analisis Nilai Tambah Ubi Kayu Sebagai Bahan Baku Keripik Singkong di Kabupaten Karanganyar (Kasus Pada KUB wanita Tani Makmur). Skripsi Fakultas Pertanian Universitas Sebelas Maret. Surakarta. 